\title{
Britt Fagerheim
}

\section{Taking the sting out of tax season A reference department/school of accountancy collaboration}

$\mathbf{T}^{2}$ ax services have often been a contentious topic in libraries. How much and what kind of tax-related information a librarian can provide is debated, bringing up questions of ethics and legality. ${ }^{1}$ Through a partnership with the College of Business School of Accountancy, the Merrill-Cazier Library at Utah State University (USU) has been able to take a proactive role in providing tax services in the library, to the bene $t$ of library users, librarians, and business students. The bridge between the library and the School of Accountancy is the VITA program (Volunteer Income Tax Assistance), which assists the community with completing and ling federal and state tax forms.

\section{VITA program}

VITA, a federal program, provides tax assistance to low-income individuals, individuals with disabilities, non-English-speaking taxpayers, and the elderly, who might otherwise not have access to tax preparation information. ${ }^{2}$ Trained volunteers assist community members with preparing basic income tax returns. VITA centers for tax assistance are usually found in schools, libraries, neighborhood centers, and shopping centers. Many places now also offer free electronic ling.

The VITA program at USU is administered by the local chapter of the Beta Alpha Psi National Accounting Honor Society. Accounting students at USU who are accepted as volunteers in the program undergo extensive training before beginning their work with the community. Students have typically completed several accounting classes in their course of study and must complete a test before they begin their volunteer service. The role of ac- counting students in VITA programs located at or near colleges is not unique. ${ }^{3}$ However, through the partnership between the library and the accounting department, the library is able to offer additional services to complement the VITA program and take some of the burden off the reference staff.

\section{VITA/library partnership}

The VITA program has traditionally been located in the Merrill Library at USU. Since 1994, the library has hired student tax assistants to help with the tax services. The tax assistants are students currently enrolled in the accounting program; referrals have come from the VITA advisor and past student assistants. The tax assistant is hired by the reference department, with the charge of distributing and organizing federal and state (Utah and Idaho) tax forms, helping patrons choose the correct forms, answering questions about the forms, and helping patrons to prepare to work with VITA.

Helping international students choose the correct forms is also a key service. The tax assistant also serves as a liaison between the reference department and VITA. Funding is provided from the library reference budget.

As the library prepared for a move to a new building in the fall of 2005, the VITA program moved to a computer-equipped room in the business building. The tax forms and library tax assistant have remained in the library. The library tax assistants have served as a bridge between the service of offering tax forms by

Britt Fagerheim is reference librarian at Utah State University, e-mail: britt.fagerheim@usu.edu

(c) 2007 Britt Fagerheim 
the library and the VITA program. The two students employed as library tax assistants in 2006 also worked as VITA volunteers, and were therefore able to answer questions about VITA and refer people to the program when necessary.

The joint library/VITA program has received extensive advertising from the student newspaper, the Utab Statesman, as well as through bookmarks, yers, Web pages, and posters. Reporters at the Utah Statesman have conducted interviews with the library tax assistants and VITA volunteers and published articles about the program. In addition, the director of USU media relations has, at times, sent out the story to local media outlets.

The free tax forms are ordered from federal and state agencies. Federal forms are ordered from the Internal Revenue Service; these forms are available in preset packages, with additional forms available by request. Because USU is located near the Idaho border, and many USU students are from Idaho, the library provides state forms for both Idaho and Utah.

\section{The emergence of electronic forms}

Despite the emergence of electronic tax forms and electronic ling, we have seen a continued demand from the public for print forms. There are very few locations in the area offering tax forms. The federal instruction books are especially sought-after. For the Utah forms, the instructions and the form are together in one book. However, the library tax service has evolved due to the advent of electronic forms. For example, we have ceased to order binders of reproducible forms in favor of using the printable online forms.

\section{Benefits of the program}

In addition to the assistance provided to individuals needing help lling out their tax forms, the accounting students and reference librarians nd bene ts in the program.

Accounting students gain valuable experience working with the community and putting their education and tax skills in practice. During the past year, the librarian

\section{Highlights from CQ Press Reference}

In print and online-your source for reliable facts and analysis

2006 Choice Outstanding Academic Titles

CQ Researcher Plus Archive 8 $\circledast$

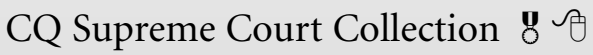

International

CQ Global Researcher $\theta$

Political Handbook of the World $2007 \mathbb{[ D}]\}$

Political Handbook of Asia 2007 [D]

The Middle East, 11th Edition $\mathbb{E d}$

The Contemporary Middle East $\mathbb{[ D}]$

Constitutions of the World, 3rd Edition $\mathbb{[ d}$

Visit us at ACRL Booth \#844 for special discounts, online demos, and free giveaways!
U.S Government and Politics CQ's Politics in America 2008 때 Guide to the Presidency, 4th Edition $\mathbb{E D}$ Historic Documents of 2006 메 $\}$ Washington Information Directory 2007-2008 미 - B

Vital Statistics on American Politics 2007-2008 매] $\}$

Guide to Congress, 6th Edition 때 African Americans in Congress $\mathbb{E} d$

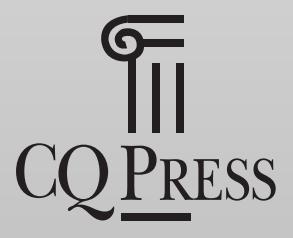

WWW.CQPRESS.COM 
coordinating the tax service in the library served as a reference for one of the library tax assistants when she applied for a summer internship.

For reference librarians, the library tax assistant program and the VITA program both provide frontline librarians with a convenient service to refer patrons to for their tax questions. In the case of the library tax assistant and the tax forms, the service is located in the library, and therefore patrons can be taken directly to the room where this service is offered. Locating tax assistance away from the reference desk takes pressure off the reference staff. They no longer need to explain why they cannot offer tax assistance or try to offer assistance to patrons in an area in which they are not necessarily well quali ed. A Web page hosted on the library Web site provides information to both patrons and reference staff, with hours the service is available, links to online forms, and periodic updates. The page is featured as a link from the library homepage from mid-January to mid-April.

\section{Conclusion}

For an academic library, services available in the academic community or the library, such as VITA, provide opportunities for collaboration to serve patrons.

As a student tax assistant stated, I felt I gained a deeper understanding as I helped others while taking my tax class and doing VITA ... The people that knew about it were very grateful for the help. The bene ts of the collaboration are seen by librarians, patrons, and students.

\section{Notes}

1. Tony Greiner, Tax help at the library, Library Journal 127 (2002): 58.

2. Additional information on the VITA program can be found at the IRS Web site: www.irs. gov/individuals/article/0, id=107626,00.html.

3. Annette Nellen, Christine Bauman, Nancy Nichols, Susan Anderson, and Ed Outslay, Pro-Bono Tax Services: The Role of Tax Academics and Students, Tax Adviser 36 (2005): 500 504. 几

\section{The definitive reference on special education \\ -now in a new edition!}

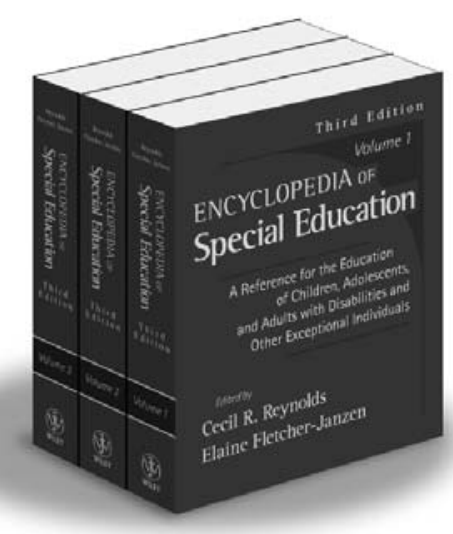

Encyclopedia of Special Education, $3 e$

Edited by Cecil R. Reynolds, Ph.D., TEXAS A\&M UNIVERSITY AND Elaine Fletcher-JanZen, Ed.D., University of Colorado, Colorado SPRINGS

0-471-67802-3 • Cloth $\bullet 2,000$ pp January 2007
The Third Edition of the highly acclaimed Encyclopedia of Special Education offers a thoroughly revised, comprehensive A to Z compilation of authoritative information on the education of those with special needs.

COMPLETELY UPDATED-SOME OF WHAT'S NEW IN THIS EDITION

- Latest information regarding the reauthorization of the Individuals with Disabilities Education Act (IDEA)

- Comprehensive coverage of No Child Left Behind (NCLB) legislation and guidelines

- Reviews of new assessment tests and curricula

All articles are cross-referenced, and citations guiding readers to related sources appear at the end of each entry.

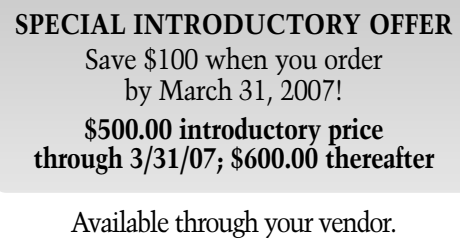

Available through your vendor. 